\title{
Mitford on the formation of control systems in Athens and Sparta before the Peloponnesian war
}

\author{
Nikolay Yasnitsky ${ }^{1, *}$, Nikolay Smolensky ${ }^{1}$, Ivan Zhiryakov ${ }^{1}$ \\ ${ }^{1}$ Moscow Region State University, 10A, Radio str, 105005, Moscow, Russia
}

\begin{abstract}
The paper, historiographical by its nature, aims at examining the existing assessments of William Mitford's work and clarifying his interpretations of the particularities of the formation of political systems in Athens and Sparta before the start of the Peloponnesian War. The paper concludes that W. Mitford's interpretations of the causes and characteristics of the formation of political systems and his description of the domestic political situation in Athens and Sparta are based on taking into account the objective, and above all, the material interests of various social strata of the population. An analysis of the work of W. Mitford revealed no distortions, arbitrary interpretation or preferences when choosing the text of ancient authors used by W. Mitford as sources. The main conclusion is that it was the democratic system of government founded by Solon, being itself a consequence of inequality of ownership that predetermined further upheavals and the expansion of the political struggle, while in Sparta the involvement in the political struggle decreased during the wars. Revision of assessments of interpretations and ideas of W. Mitford suggests the need to clarify the features of English historiography of the Enlightenment.
\end{abstract}

\section{Introduction}

Evaluation of the scientific heritage of William Mitford (1744-1827) since the publication of the first volumes of his History of Greece has undergone significant changes in foreign and domestic historiography. If at the beginning of the XIX century. his "History of Greece" was the subject of political discussions between liberal and Tory historians (see $[1,2])$, then from the middle of the XIX century his work was evaluated predominantly negatively (see [3-9]). The most significant criticisms boiled down to the fact that his presentation of the history of Greece is only the political history of Greece and is written with political "bias", which was manifested in the praise of monarchical or "oligarchic" orders and the censure of governance systems in "democratic" republics, the distortion of sources and their "selectivity". According to many researchers, such distortions by Mitford of the history of Greece were associated with the events of the French Revolution and led to unjustified "parallels", one of such examples is, as T. Pyardon considered, an identification

\footnotetext{
* Corresponding author: yasnitsky@bk.ru
} 
of the tyranny of the Thirty and the Committee of Public Salvation [5]. Purpose of the paper: determination of W. Mitford's interpretation of the conditions that predetermined the different paths of political development of Athens and Sparta before the Peloponnesian war. The authors revealed both similarities and differences in the explanation of W. Mitford of the causes of reforms and events with the philosophical and historical concepts of his contemporaries.

\section{Materials and Methods}

The source was the work of Mitford W. The History of Greece: 12 v. - London: Luke Hansard \& sons, 1808., The authors analyzed, based on comparative historical, biographical methods, the main studies devoted to William Mitford and the English historical science of the Enlightenment, the works of Herodotus, Thucydides, Plutarch, Diodorus, Strabo, Aristotle and other ancient historians mentioned by Mitford. A comparison of the History of Greece by W. Mitford with the works of ancient historians and studies of the specific history of Greece by modern British and Russian authors made it possible to put forward the assumption of an inaccurate presentation, and in some cases a distortion in the historiography of the theoretical basis and historical views of William Mitford.

\section{Results}

One of the criticisms of a general nature, which in historiographical works is characteristic of most scholars of Mitford's heritage, is that his Greek History is a political history.

However, considering the early period of the history of Greece and addressing the problem of the appearance of civilization and states in Greece, Mitford suggests that the emergence of Greek civilization is primarily due to relations with the countries of the East, as the natural conditions were not as favorable on the Balkan Peninsula as in Nile Valley. However, considering the early period of the history of Greece and addressing the problem of the appearance, but with a further comparison of natural conditions and lifestyle in Europe, Asia Minor and the Balkan Peninsula, Mitford comes to a slightly different conclusion, based on several arguments. Firstly, those who moved to Europe found countries overgrown with forests and inhabited by animals only. "their life was thus spent in action: they spied far- had few neighbors; and, with those few, little intercourse. Such people were inevitably barbarous: but they would, much sooner than more civilized people, give inhabitants to every part of the globe" [10]. Consequently, those who moved to the Balkan Peninsula and islands in the Aegean Sea had to have good reasons for resettlement. But as Mitford notes, "Security from savage beasts, and men as savage, would be the first solicitude of families; and this those islands would seem to promise in a greater degree than the continent. Other islands appearing beyond these, and beyond those again still others, navigation would here be almost a natural employment. The same inducements would extend to the coasts of the continent of Greece, indented as it is with gulphs, and divided into peninsulas" [10]. Besides, "the beasts of prey, with which the old world has always been infested so much more than the new, have contributed not a little to the quicker progress of society and civilization" [10]. To find an answer about the reasons for the resettlement, Mitford builds another line of reasoning; security from neighboring tribes and wild animals could lead to the formation of certain communities or unions that could not be sustainable for several reasons. The first, according to Mitford, is a tendency to migration, which, according to the theories of his time, appeared when the territory was overflowed with a population that did not know not only production and trade, but also regular 
agriculture. But exactly "in very early times we find Greece over run by many different people, of whom the Greek writers in the most heightened ages could give no satisfactory account. Some came land from the north; some by sea from the cast or south; some mixed amicably with the antient inhabitants; some subdued or expelled them" [10]. As a result of these two circumstances, "The rich vales, which without cultivation would give large support for cattle, were the coveted territories; and these were continually changing their possessors. Of the expelled, some wandered in quest of unoccupied vales; or in their turn drove out the inhabitants of the first they came to, if they found them weaker than themselves" [10]. "Others took to the neighboring mountains; and thence, harassing the intruders, not unfrequently recovered in time their old settlement in the vale. When pressed by a superior force, any of them (putted their possessions with little regret; 'thinking,' as Thucydides observes, 'that a livelihood might ' be had anywhere, and anxious for nothing more: for being always ' uncertain when a more powerful clan might covet their territory, ' they had little encouragement to build, or plant, or provide in any ' way farther than for present need."' [10].

Mitford makes a completely unexpected conclusion. "Greece thus, in its early days, was in a state of perpetual maroding and piratical warfare. Cattle, as the great means of subsistence, were first the great object of plunder. Then, as the inhabitants of some parts by degrees settled to agriculture, men, women, and children were sought for slaves. But Greece had nothing more peculiar than its adjacent sea; where small islands were so thickly scattered, that their inhabitants, and in some measure those of the shores of the surrounding continents also, were mariners by necessity, and almost by nature. Water-expeditions, therefore, were soon found most commodious for carrying off spoil" [10]. Emphasizing the influence of natural factors, Mitford does not deny the influence of the Phoenicians. In his opinion, the Phoenician occupations, their ingenuity, and the risky spirit of trade, forced them to explore the far shores of the Mediterranean early and risk the dangers of the ocean in search of deposits of gold and silver on some islands of the Aegean Sea, and off their northern shores. As a result, the Phoenicians "formed establishments in several of the islands and Thasus, which, having itself mines of both silver and gold, lay conveniently also for communication with the most productive of the continent, became the seat of their principal factory" [10]. As a result, according to Mitford, countless islands and ports, which provided the only opportunity for attack, were the most powerful incentive for piracy at sea. And, therefore, hostilities should have been a natural and honorable occupation of the Greeks [10]. To confirm his assumption, Mitford refers to historical examples and to the customs of modern times. "It is not very long since robbery was held in esteem among the native Irish; and a hospitable highland Scottish chief, proud of his fabled descent from kings and heroes, would have boasted of his achievements in that way: in Sicily such sentiments even yet prevail; and among all the Arabian tribes, from the middle of Asia to the end of Africa, the idea of union between honor and robbery has been transmitted unaltered through hundreds of generations" [10].

Mitford does not exclude the likelihood of the influence of Cretan civilization on the characteristics of the life of the Greeks of this period. Mitford considers it necessary to consider this version due to the fact that in his time it was Crete that became the main object of attention for collectors of antiquities, "antiquaries". Mitford emphasizes that according to the laws of Antiquaries of Crete were not just a specific model of a remarkable form of government, which is well known to us because of the glory of Lacedaemon, but was a common source of Greek law and jurisprudence [10]. Mitford believes this explanation is not reliable enough, since the history of Minos was passed on to the descendants in the Iliad so vaguely that among Greek authors the question remained unresolved whether he himself was a native of Crete or he was a foreigner. In addition, according to Mitford, in fact, we do not have data for any coherent Greek history, not only 
before, but even after the era of Minos; we have at our disposal only fragments of the most respected authors who evaluated their way of government in general only [10]. And finally, he emphasizes, this is not compatible with two principles: that free people should be all equal, and that equality cannot be ensured by slavery [10].

Thus, comparing the interpretations, Mitford concludes that "It is difficult to account for the first establishment of such a system, but upon the supposition that a band of adventurers, from the polished countries of the east, seizing the lands, like the Spaniards in the West-Indian islands, deprived the antient inhabitants of arms, and compelled them to labor. Accordingly, we find it remarked that the Cretan constitution was not that of a civil, but of a military community; not so much of a state as of a camp" [10].

This assumption is supported, according to Mitford, also by evidences of a greater closeness of the inhabitants of the Peloponnese in their way of life and management system to the Thessalians than to the Phoenicians or Egyptians. The leaders of the tribes who conquered one or another territory there and founded small settlements did not have absolute power like the Asian kings. At the same time, as stressed by Mitford, we find no mention of republic at Homer, and all the other authors did not report the existence in these early days of that control system in Greece. [10]. According to Mitford, Homer's testimony is especially valuable, since the poet himself was a supporter of the monarchy and tried to mention this at every opportunity [10]. Nevertheless, it is Homer, as Mitford emphasizes, who informs us of such rules of government in Greece, which are more likely to indicate about "the mixture of monarchy, aristocracy, and democracy, is not less clearly marked than in the British constitution. One chief, twelve peers (all honored like the chief with that title which we translate King) and the assembly of the people, shared the supreme authority. The universal and undoubted prerogatives of kings were religious supremacy, and military command. They exercised also judicial power. But in all civil concerns their authority appears very limited" [10]. According to Mitford, the control system in this early period in Greece was the same as that of our Teutonic ancestors [10].

Analyzing the causes of Athens appearance in the "heroic" period, Mitford again starts with the definition of the natural conditions that led the settlers to build a city here. "On the verge of a plain, watered by two small streams, a haven presented itself, commodious for the vessels of the time. Between the streams, near their junction, about three miles, from the shore and five from the haven, a rock, 'rising nearly perpendicular on all sides, had every advantage for a fortified post. Precisely this union of circumstances was what the early Greeks most desired for the situation of a city" [10]. Clarification of the natural conditions that contributed to the appearance of the cities of Greece at Mitford is constantly found, however, in his opinion, this was not the circumstance that was decisive and main in this case. "Such was that of Argos, with its citadel Larissa and port of Nauplia, Corinth, with the Acrocorinthus and port of Lechxum, and many others; and Edinborough, with its castlerock and its port of Leith, affords a perfect exemplification of it. Mountains, but not of that formidable height common through Greece, at some distance surrounded the plain; which are not of the first fertility, appeared yet not adverse to cultivation. Cecrops occupied the rock, and, how far by force, how far by persuasion, we are not informed, he extended his dominion over the whole tract afterward called Attica" [10]. Among the main conditions that contributed to the emergence and prosperity of Athens during the reign of Cecrops, Mitford mentions a number of circumstances, referring to Strabo and Plutarch: these are both security and religious considerations. "He divided this territory into twelve districts, with a principal town, or rather perhaps village, where he caused justice to be administered according to some (Strab.I.9. p -397. Plutarch. Thes.) salutary laws which he established; and he taught his subjects a more regular and effectual mode of defense against the incursions of the Boeotians, their only neighbors $\langle\ldots\rangle$. The fortress, which he made his residence, was from his own name called Cecropia, and was peculiarly recommended to the 
patronage of the Egyptian goddess, whom the Greeks worshipped by the name of Athena, and the Latins of Minerva. Many, induced by the neighborhood of the port, and expecting security both from the fortress and from its tutelary deity, erected their habitations around the foot of the rock; and thus arose early a considerable town which, from the name of the goddess, was called Athenai, or, as we after the French have corrupted it, ATHENS" [10]. It seems that, by comparing the natural, political and religious circumstances Mitford gives a big role to security reasons from the attacks. However, his general theoretical conclusion, nevertheless, testifies to the main role of other circumstances: natural conditions and the influx of population. "Attica was the province of Greece $\langle\ldots>$ where the earliest progress was made toward civilization. Being nearly peninsular, it lay out of the road of emigrants and wandering freebooters by land; and its rocky soil, supporting few cattle, afforded small temptation to either. The produce of tillage was of less easy removal, and the gains of commerce were secured within fortifications. Attica therefore grew populous, not only through the safety which the natives thus enjoyed, but by a confluence of strangers from other parts of Greece $<\ldots>$ people commonly resorted to Athens, as the only place of permanent security, and where strangers of character, able by their wealth or their ingenuity to support themselves and benefit the community, were easily admitted to the privilege of citizens" [10].

Referring to the period of Solon Mitford, before analyzing Solon's reforms themselves, a whole chapter of his work dedicates to a description of the political situation prior to his reforms. Thus, Mitford, in essence, raises the question of the necessity and regularity of the transformations of Solon. He emphasizes that in Athens, as in all the ancient republics "we find violent agitations resulting from inequality of property: the principal division of the people was into the faction of the rich and the faction of the poor, and the animosities between these were vehement, and the contests marked with acrimony" [10]. Inequality in ownership of property was compounded by inequality in power. "Put the oligarchal principle yet predominated in the Athenian constitution. The claims of birth were high: civil magistracy, religious office, military command, all remained, as they had been appointed by the laws of Theseus, the exclusive privilege of the eupatrids: almost the whole property of Attica was theirs; and it appears that the consequent oppression of the lower people was often severe" [10]. That's why Solon, "more yielding to the temper of the times and the difficulty of circumstances than pursuing what himself thought best, having confirmed to the Assembly of the People an authority more universally and uncontrollably absolute than any despot upon earth ever did or ever can possess, his great concern was to establish some balancing power, capable in some degree of obviating the evils which a sovereign multitude is ever ready to bring upon itself' [10].

Anticipating the description of Solon's reforms, W. Mitford emphasizes that it is difficult, or almost impossible, to establish, using even the most accurate selection, what remains of various ancient authors, what was and what was not in his reforms [10]. Although the statement of Solon's reforms does not contain any novelty, because Mitford based, as modern writers on the information gleaned from the writings of Aristotle, Herodotus, Plutarch, Diodorus, and Xenophon, his attitude to the reforms of Solon is interesting.

Mitford mentions both the Council of Archons, and the Areopagus, and the Council of Four hundred and characterizes the latter as follows, "Solon instituted a new Council or Senate, consisting of one hundred persons out of each of the four wards which composed the Attic people. Such an assembly, he hoped, would have a weight which the college of Archons had been unable to maintain; and he therefore committed to it many of the powers which had before belonged to those magistrates" [10]. To his main functions, Mitford relates that "of this council to prepare business for the Assembly of the People; in which, according to Solon's constitution, nothing was to be proposed which had not first been 
approved here. But the powers which he had already ratified to that assembly were too preponderant for any certain restraint. Whenever, at the instigation of a factious demagogue, it desired more, it might demand and take" [10,11]. Mitford's general conclusion is at odds with Solon's traditional assessment of reform: "He intended indeed that the councils of the Areopagus and of the Four hundred, afterward Five hundred, should balance the authority of the popular assembly; and they might have been effectual balances to a body representative of the people; but against sovereign power, committed immediately to the people at large, no balance could avail. Interested demagogues inciting, restraint was soon overborne, and so the Athenian government became $<\ldots>$ A TYRANNY IN THE HANDS OF THE PEOPLE” $[11,12]$.

Mitford believes that Solon laid the foundation for the future death of Athens. "Solon was not unaware of the evils inherent in that turbulent form of rule; and he proposed to obviate its inconveniencies, by the establishment of balancing powers. But the great resource of representation and delegated authority, the not unknown among the Greeks, seen in earliest times in the council of Amphictyons, and afterward in national congresses, was however nowhere so arranged as to afford any very promising example. Solon therefore gave supreme power to the people in assembly, where every free Athenian had his equal right to vote and speak; a foundation of evil so broad, that all the wisdom of his other regulations was weak against it" [10]. Besides, "but as it was a power that could only be maintained by still cultivating the democratical interest, to the utter overthrow of the aristocratical, and the destruction of all balance in the constitution, the result was ultimately most pernicious to the commonwealth, and involved incalculable evils for all Greece" [11].

Mitford reveals features of the Spartan management system based on an analysis of the political situation on the eve of Lycurgus reforms. Mitford cites the legend of Lycurgus' voluntary cession of power, his voluntary expulsion and the unrest that occurred at that time. Judging by the information of Plutarch, as Mitford emphasizes, one could "finding it, therefore, no season to attempt that reformation in the state which be wished" [10]. But in contrast to Plutarch, Mitford considers this period of political anarchy a favorable situation for the implementation of Lycurgus's plans, which he outlined during his travels. The peculiarity of the situation was, according to Mitford, that while Lycurgus was absent, "the kings were without authority, the laws without efficacy, the anarchy was extreme, and all ranks suffered" [10]. As a result, Lycurgus created his own political "fraction" because "regal power, weak through division, leaned sometimes on either faction, and sometimes took opposite parts, unable to hold the balance between the two" [10].

Further political events in Sparta Mitford poses such a way that it becomes clear: the reforms were carried out without the consent of the majority of the population. The main role was played by the armed adherents of Lycurgus [10]. The essence of the well-known reform of Lycurgus, Mitford passes, like the majority of modern scholars, referring to Aristotle. Mitford stresses that the greatest outrage among Lycurgus's reforms was caused by measures leading to the destruction of property! "The more completely to insure equality, and to repress every desire of superfluities, he directed that none should refuse ${ }^{-}$to lend whatsoever he was not immediately using, and that any might take, even without asking, whatsoever be wanted of his neighbor's; being only bound to replace it undamaged. Private property thus was nearly annihilated" [10]. And yet, according to Mitford, the course of Lycurgus's reforms was relatively peaceful for several reasons, and all of them were connected with material interests. Firstly, "principal land-owners were persuaded to part peaceably with their possessions, that they might preserve their authority: foreseeing probably that resistance would but occasion the loss of both. Thus it was effected in Lacedaemon that extraordinary division of lands, which allotted to every family an equal share, and banished, according to Plutarch's expression, ail distinction between, man and man, other than what arose from the praise of virtuous, and the' reproach of unworthy 
deeds. The whole territory of Laconia was divided into thirty-nine thousand shares, nine thousands of which were assigned to the city of Sparta, the rest to other townships" [10].

Mitford gives his own assessment of Lycurgus's reforms, criticizing the opinions of contemporary philosophers and historians. "It has been a fancy of some modern authors, that the institutions of Lycurgus but the revived usages of the heroic ages; and of others, that they those of the rude Dorian highlanders, improved and systematized. All antiquity contradicts both opinions, and particularly the writers of highest authority. Xenophon not only refers everything expressly to the legislator, hut affirms that Lycurgus established his plan of government upon principles diametrically opposite to those of all other Grecian states, without any exception for the Dorians, either in their new or their old establishments; and Thucydides, and Isocrates, and Plato, and still more Polybius, speak strongly to the same purpose" [10]. Mitford regards Lycurgus's reforms as the changes that provided Sparta with a longer existence compared to other republics, and which made it possible to ensure this without violence, since "preserving civil freedom and political concord within the state, and of securing it against all violence from without the institutions of Lycurgus seemed to have been conceived with more than human wisdom" [10].

Comparing the political changes made by Solon and Lycurgus, Mitford emphasizes the different outcomes of these changes, although they were based on the same socio-economic reasons. "Like Lycurgus, Solon's first object, and what indeed the state of things at Athens most urgently demanded, was to remedy the evils produced by inequality of possessions; to reconcile the rich with the poor, to relieve these without violently offending those" [10]. The reason for the different outcomes of Lycurgus and Solon's reforms, according to Mitford, is that "Solon would obviate the abuse, not abolish the use of riches. The business was of extreme nicety" [10].

After the reforms of Solon, Mitford associates political changes in Athens with Pisistratus. And in this case, the interpretation of his rise to power, the characteristics of his rule and his reforms are closely linked by Mitford with the economic consequences of the reforms of Solon. "What one party then approved in Solon's laws, the others of course would desire amended, and what these would be most satisfied with, the former would be most eager to alter. Himself thus involved in difficulties, and his great work of legislation in much danger" [10]. After Solon returned from his travels, the struggle of the fractions in Athens acquired an armed character, and he could no longer calm the storm and lead to a union of irritated minds. The matter reached a critical point when the injured Pisistratus arrived on the agora in his chariot, reported that he was attacked by his political opponents and received the right to assemble an armed detachment for protection [10]. Mitford, doubting the authenticity of the details reported by ancient historians, believes "what stands ascertained is, that Peisistratus with his guards seized the citadel; that his party supported him; and that their opponents were forced, part into exile, the rest to submission. Peisistratus, as leader of the prevailing party, was of course the first man of the commonwealth, and henceforward he is called by historians Tyrant of Athens" [10]. Mitford is convinced that the term "tyrant" in the modern meaning of the word is not applicable to Pisistratus, since according to Herodotus he did not change anything in the laws of Athens, all the authorities acted under him [10]. Mitford also mentions the economic reasons for the strength of the power of Pisistratus. "Finding an increasing disposition in the Athenians to neglect rural employments and crowd into the city, he took every method to discourage this, and promote agriculture; giving liberally from his private property; especially if by the same act he could reward merit or relieve distress. The laws against idleness, attributed by some to Solon, are also ascribed to Peisistratus. The law decreeing a public provision for the wounded in their country's service, is referred to him alone. He was eminent for love of learning and the fine arts. He is said to have founded the 
first public library known in the world; and the first complete collection and digestion of Homer's poems is by Cicero attributed to him" [10].

Another significant change in the management system was made by Klisfen. According to Mitford, he did not possess the abilities necessary to maintain power in a democracy [10]. That is why, when the Isagore group began to act against him, relying on influential aristocrats and wealthy sections of the population, Klisfen was forced to expand the rights of the lower layers. "The resource of Cleisthenes was therefore among the lower people. These being all-powerful in the general assembly, by their means he made some alterations in the constitution, favorable to his own influence: particularly he divided anew the Athenian territory and people; instead of four, making the number of tribes ten, to which he gave entirely new names. It appears from Herodotus that Cleisthenes was at this time not less tyrant of Athens than Peisistratus had been" [10]. Mitford emphasizes that the changes under Pisistratus, and even more so under Clisthenes, destroyed the balance of power that Solon created: "the passions of the multitude and the interest of demagogues met; and, before the Persian invasion, we find the whole revenue from the 8 silver mines distributed among the people" [12].

The political order in Sparta, according to Mitford, did not change significantly for a long time, until the end of the Peloponnesian War. However, still "while, in other Grecian states, the tyranny of the one king drove the multitude to assume, by violent means, the supreme power to themselves, in Lacedemon the concessions of the two gave bv degrees such importance to the people, that the royal authority scarcely remained an object of cither terror or envy. Thus, however, powers of government were at length, so weakened, that the worst of all tyrannies, anarchy, prevailed in Sparta" [10]. However, the influence on this situation, as Mitford emphasizes, was exerted by both talented individuals and external wars. "The evils of this lawless situation appear to have been sometimes checked by abler princes, who the contentious spirit of the people to exert itself in foreign wars, in which sonic successes were obtained" [10].

In Athens, by contrast, wars, and especially the Greco-Persian wars, led to new upheavals and reforms of the governance system. Mitford's attitude to the consequences of the reforms of Pericles is sharply negative. Since the main powers of the Areopagus and especially its beneficial control over the treasury were abolished, and when Pericles's abilities ceased to restrain people's extravagance "there followed the grossest dilapidation of the public money, the most tyrannical oppression of the allies, and the most profligate exercise of the purest despotism over the most respectable citizens. Fine and confiscation were looked to less for the purpose of justice than of revenue. The temptation to speculate, the insecurity of innocence, and the hope for crime to escape punishment, became such, that, amid the general depravity of Grecian governments, Athenian peculation grew proverbial: and it was at the same time made a question, whether it was advanta posgeous for an individual to have property, and whether it was advantageous for the commonwealth to have a revenue" [12]. In addition, another irregular tax that did not exist under tyrants was often levied under Pericles and during periods of further rule of the democratic "party". "This, a tax also upon the higher ranks only, and perfectly arbitrary, could not fail to become partial and oppressive in extreme. Among taxes partaking of the nature of free-gifts may also be reckoned the requisition for the rich to exhibit, at their own expense, theatrical entertainments, and other costly shows, for the amusement of the people; taxes severely felt by the higher ranks, though contributing nothing to the public revenue or the public force" [12]. Reforms of Pericles, according to Mitford reflected in the foreign policy of Athens also: "Athens, in acquiring extensive dominion, acquired means to make others pay the principal expense of that force which was to maintain her dominion; and a democracy, least of all governments, would scruple any means of profit. The comic poet, one of the most informed and clear-sighted politicians, and, however reprehensible in some points, very far 
from having been altogether the worst citizen of his age, has painted the popular temper of the day in a speech so breathing the purest spirit of democracy, that, though already noticed, it may not be superfluous to repeat it here. "A thousand cities, "it is observed by one of the characters in his comedy called The Wasps, "pay tribute to Athens. Now were each ordered to furnish subsistence for only twenty Athenians, twenty thousand of us might live in all ease and luxury, in a manner worthy of the dignity of the commonwealth and of the trophy of Marathon" [12].

During the Greco-Persian war, after the death of Pericles, the reforms of Aristide, according to Mitford, were forced due to economic and social changes. Athenians "were ready to serve the commonwealth, because they were the commonwealth: having fought for their existence, they were ready still to fight for glory and power; but it must be for themselves, not for others as their superiors. Argument, such as will weigh with the people, and orators to urge it, may always be found in favor of the popular cause; and so irresistible the torrent of popular ambition became that even Aristides was reduced to temporize, so far as not only to admit, but to promote, a very great change in the constitution of the government" [11]. Mitford characterizes the essence of these social changes quite negatively. "The laws of Solon had gone far to level distinctions of birth: all Athenian citizens were reckoned sufficiently noble to execute the highest offices in the commonwealth, the priesthood only excepted; though for civil offices a qualification by property was yet required. This restraint was now wholly done away. In the actions of Marathon, Salamis, and Plataea the poor had contributed equally with the rich to save and to ennoble their country. All civil and military offices were therefore laid open, not only to those of meanest birth, but to those totally without property; and the most important of the civil offices being conferred by ballot" [11]. It is for these reasons that the further struggle of the two political groups, led by Aristide and Themistocles, ended with the ostracism of Aristide. Mitford does not report on specific reforms of the management system of Themistocles, with the exception of his "maritime program". In his opinion, it consisted in the successful struggle of Themistocles with the ancient policy of the Athenian government aimed at abandoning the development of maritime trade in favor of agriculture as the basis of external security and internal stability. This struggle of Themistocles, as Mitford emphasizes, was due to his understanding of the reality of the threat of the destruction of Athens during the Persian invasion. The Athenians had no choice but to die or evacuate the population to the nearest islands with the help of the fleet [11]. According to Mitford, after the battle at Thermopylae, in view of the threat of the destruction of Athens, the political struggle of the Aristide and Themistocles groups escalated, although Aristide himself was in exile. Supporters of Aristide from an aristocratic group tried to use the powers of the National Assembly to counter the omnipotence of Themistocles. And in the conditions of the crisis of the republic, Themistocles was captured by his popularity, and generously he himself proposed a decree that allowed his rival to return [11].

So, it seems obvious that Mitford's interpretation of events related to the period of the political struggle of Themistocles and Aristide during the Greco-Persian war is reduced to emphasizing the role and influence of purely military danger, while the role of material circumstances and the influence of property interests are only slightly outlined, but not highlighted as the main.

\section{Discussion}

A wide circle of acquaintances of W. Mitford among historians and writers, his involvement in political activity and the fact that historical parallels became an argument in the political and ideological struggle, all this suggests the existence of a special version of English historical thought of the Enlightenment. 
An appeal to the history of ancient Greece became especially important in connection with the loss by Great Britain of its colonies in North America, and the intensification of the political struggle both in Great Britain itself at the end of the XVIII century and under the influence of the events of the French Revolution.

According to the results of the study, accusations of political bias, the opinions about the lack of consideration of the influence of economic and other material factors in Mitford were not confirmed, these accusations should not be attributed to Mitford, but to his critics, and they are caused by the dominance of liberal views in historical science.

The revealed peculiarities of W. Mitford's interpretations of the formation of the political systems of Athens and Sparta allow us to continue revealing the uniqueness of his historical and philosophical views on other problems of the history of ancient Greece. Especially fruitful would be the definition and comparison of his ideas with the views of other historians, close to the Tory party, on the causes of the death of the ancient republics, the collapse of the A. Macedonian empire, and the death of the Roman Empire.

Seems fruitful too the comparison of William Mitford's interpretations of causes and consequences of the main events and processes with relevant explanations of specific problems of ancient Greece by modern historians, since the authors found many coincidences with the interpretations of Mitford in the History of Greece by N. Hammond, the writings of V.M. Strogetsky, I.E. Surikova, L.P. Marinovich and others.

\section{Conclusions}

When analyzing political changes, W. Mitford takes into account both natural-geographical, and social and economic circumstances. The authors did not find confirmation that the criticism of the political system of Athens was caused only by his political preferences. Mitford's criticism of the "democratic system" in Athens is based on the fact that inequality of ownership in Athens was not eliminated under this system, which led to a greater degree of involvement in the political struggle than in Sparta, and gave rise to a desire for an everexpanding power of the lower social strata. The political struggle in Athens, unlike Sparta, escalated during the wars, which also did not contribute to the strengthening of the state.

If we ignore the details, and pay attention to Mitford's interpretation of the essence of the reforms of Lycurgus and Solon, then, in our opinion, the common is a "mixed rule". The peculiarity is that, according to the reforms of Solon in Athens, the aristocracy by origin was replaced by the aristocracy by "wealth" and at the same time the source of the political struggle did not disappear, but intensified. The reason for this is that the desire for enrichment and prosperity has acquired an individual character, which has led to greater inequality of property and an even greater political struggle that has captured all social layers of citizens. On the contrary, according to Lycurgus' reforms in Sparta, an attempt was made to equate property, and the desire for enrichment and prosperity acquired a social character, and the political struggle was concentrated only in a narrow circle of royal families and ephors!

Thus, we believe that W. Mitford nevertheless links political reforms and the economy, but the essence and understanding of this connection was determined by the level of development of economic theories of his era, and this connection is based more on the distribution of material goods, rather than on their production. 


\section{Acknowledgements}

The article is based on a dissertation. In conclusion, the authors would like to thank the leadership of Moscow State Regional University for creating the conditions for the publication of this article, as well as anonymous reviewers for useful recommendations.

\section{References}

1. H. Brougham, The Edinburgh Review IV(12) 478 (1808)

2. A. Alison, History of Europe from the Fall of Napoleon in MDCCCXV to the Accession of Louis Napoleon in MDCCCLII 9 vol (Edinburgh and London, Blackwood, 1852-59)

3. G. Grote, History of Greece (Cambridge University Press, 2010)

4. Thomas B. Macaulay, Essays, Critical and Miscellaneous (Boston, Phillips, Sampson, 1856)

5. T.P. Peardon, Transition in English Historical Writing 1760-1830 (N.Y., Columbia Univ. Press, 1933)

6. E. Rawson, The Spartan Tradition in European Thought (Oxford, Clarendon Press, 1969)

7. J.A.W. Gunn, Beyond Liberty and Property: The Process of Self-Recognition in Eighteenth-Century Political Thought (Kingston, McGill-Queen's University Press, 1983)

8. J.T. Roberts, Athens on trial: the antidemocratic tradition in Western thought (Princeton, Princeton Univ. Press, 1994)

9. B. Rapple, A Tory History of Ancient Greece. Contemporary Review 266(1549), 97 (1994)

10. W. Mitford, The History of Greece: 12 v vol I (London: Luke Hansard \& sons, 1808)

11. W. Mitford, The History of Greece: 12 v vol II (London: Luke Hansard \& sons, 1808)

12. W. Mitford, The History of Greece: 12 v vol V (London: Luke Hansard \& sons, 1808) 